\title{
Understanding Continuity and Change in the Persian Vernacular Settlements: A Comparative Syntactic Analysis of Urban Public Spaces in a Case Study
}

\author{
Hesam Kamalipour ${ }^{1}$, Amirali Dorrani Arab ${ }^{2}$, Sahar Soltani ${ }^{2}$, \\ Saba Naser Alavi ${ }^{2}$, Elnaz Mirzaei ${ }^{2}$ \\ ${ }^{1}$ Department of Architecture, School of Architecture and Environmental Design, \\ Iran University of Science and Technology, Tehran, Iran \\ ${ }^{2}$ Department of Architecture, Saba Faculty of Art and Architecture, Shahid Bahonar University of Kerman, \\ Kerman, Iran \\ Email: hkamalipour@iust.ac.ir
}

Received September 23 ${ }^{\text {rd }}$, 2013; revised October 25 $5^{\text {th }}$, 2013; accepted November $3^{\text {rd }}, 2013$

Copyright $(2013$ Hesam Kamalipour et al. This is an open access article distributed under the Creative Commons Attribution License, which permits unrestricted use, distribution, and reproduction in any medium, provided the original work is properly cited.

\begin{abstract}
Considering the organized complexity of the city problems, the study tends to understand the process of urban transformation concerning the relation between social and spatial practices in the public places. Thus, the study conducts a comparative syntactic analysis of the urban public spaces, within the past five decades, along with the social exploration in order to understand the process of continuity and change in the historic walled city of Naein, located in the central part of Iran. The interconnections of the people and the hierarchical structure of urban public spaces have led to a considerable spatial configuration in the walled city. Adopting qualitative and quantitative approaches, the study implements the combinational research methods including the descriptive-analytical, comparative simulation, and logical reasoning methods in the case study of Naein. Furthermore, the study uses direct observation, face-to-face interview, questionnaire, documentation, and desk study. Firstly, the paper tends to explore the social attributes of the urban public spaces in the walled city of Naein. Secondly, the study implements a comparative syntactic analysis of the integration, connectivity, and depth factor through a simulation using space syntax approach. In order to understand the process of continuity and change in a comparative study of the sociospatial relations, in the urban public spaces of the case study, the results of the paper provide a descriptive exploration of the urban transformation by reading the syntactic maps in relation to the social attributes of the case study.
\end{abstract}

Keywords: Space Syntax; Urban Public Spaces; Social Attributes; Spatial Configuration; Persian Vernacular Settlements; Naein

\section{Introduction}

The recent upcoming changes of the Persian cities in population and lifestyle have not been accompanied by a smooth transformation in urban public spaces. Considering the vernacular framework, which refers to an architectural language with a "local origin" rather than the foreign one (Kellett \& Napier, 1995), the chain of the self-generative development process of the urban public places within the Persian vernacular settlements has been broken by the recent formal changes in traditional dwellings. Consequently, the public places do not meet the people's needs anymore. On the other hand, many of the generalizations regarding density and residential districts of different income groups are not applicable to the Persian vernacular settlements (Clark \& Costello, 1973). Simultaneously, the cities of Iran are experiencing a rapid population growth within the past four decades and more than $70 \%$ of the population is living in the cities (Aghajanian, 1995). However, excluding the mythological study of the Persian vernacular architecture (Kamalipour, Memarian, \& Mousavian, 2012), the dis- cussion of everyday experience of the urban life has been largely ignored in the academic journals and research papers (Modarres, 2006). Historically, from the impacts of the capitalist relations on the Persian urban systems (since 1960) to the sequence of the population growth, and the social and economic inequalities among cities or between urban and rural areas (since 1980), the Persian cities have been experiencing considerable urban transformations within the past five decades (Fanni, 2006).

It has been previously mentioned that urban morphology of the traditional Persian cities should be considered as a reasonable solution to the real problem of accessibility for a community of the housing assemblages (Bonine, 1979). However, the parental interventions and "fixing" have widely changed the spatial configuration of the Persian historic cities in the last five decades. The historic walled city of Naein, which has various types of public spaces, encounters a similar problem. In fact, the case study of Naein, which is located in the central part of Iran, is one of the considerable models of the Persian historic 
cities in which cultural, social, and ritual activities have clearly modified the spatial configuration, community centers, and development of the city. For example, the Grand Bazaar, community centers, and the connecting pathways used to meet the people's needs and desires successfully and frame their social everyday practices. Meanwhile, the mutual interconnection of the people and the hierarchical structure of urban public spaces have led to a unique spatial configuration in the historic walled city of Naein (Kamalipour, Jalaladini, Fakharzadeh, Motedayen, \& Dorrani Arab, 2012; Soltanzadeh, 1995). Thus, concerning the spatiality of the social interconnections in comparison to the hierarchical rigidity of the urban morphology, the study tends to conduct a comparative syntactic analysis and explore the social capital of the urban public spaces in order to understand the process of continuity and change in the historic walled city of Naein.

\section{Urban Public Spaces and Social Constructs}

Public space relates to the all buildings and natural environments where people have almost free access (Carmona, Magalhães, \& Hammond, 2008). The issue of urban public space has been an evolutionary concern within the urban studies as it has been relatively considered in all definitions of urban design. Urban public space refers to the "common ground" in which people accomplish the functional and ritual activities in the regular daily life routines and periodic causes (Carr, Francis, Rivlin, \& Stone, 1992; Carr, 1992). The studies regarding the issue of urban spaces have mostly concentrated on different aspects and dimensions of the public places (Carmona, 2003; Carmona \& Tiesdell, 2007; Le Gates \& Stout, 2011) in order to improve the public realm and make desirable "people-friendly" cities (Tibbalds, 1992; Shaftoe, 2008). However, the social dimension has been studied as one of the main aspects of the place and social theory, which is closely related to the "practices of power" (Bentley, 1999; Dovey, 1999), the process of experiencing the public life in terms of different types of activities (Gehl, 1987; Gehl \& Gemzoe, 1996), and the issue of "social justice" (Mitchell, 2003). Thus, the relations between "sociality" and "spatiality" in terms of the "socio-spatial" processes are linked to the configuration of the urban public spaces (Hillier, 2008; Madanipour, 1996). In this way, the relations between social attributes and spatial configurations of the place should be considered along with the inherent complexity of the city problems. However, it is in consistency with the problem of the city as a "semi-lattice" (Alexander, 1964), which is an organized complex one (Jacobs, 1961).

Considering "the wholeness of the city" (Eade \& Mele, 2008) while referring to the interdisciplinary nature of the place studies, it has been justified that the places mediate the practices of power (Dovey, 1999, 2010). Relying on the connections rather than essences (De Landa, 2006), the formation of the places, as assemblages, are constantly in the process of becoming (Dovey, 2010). Hence, Dovey (2010) argues that place cannot be simply reduced to a "myth" (Barthes, 1973), a "text" (Derrida, 1974) or an "essence" (Alexander, 1979, 2002; Norberg-Schulz, 1980) without considering the social constructs of the place (Dovey, 2010). In this way, space is a product of the social constructs, and simultaneously it is capable of producing the sociality (Lefebvre, 1991). However, the process of everyday life tends to pursue in the relation between sociality and spatiality (Dovey, 2010). On the other hand, regardless of the economic and social processes, the formal and functional attributes of the city cannot be understood without considering their emergent specific geometrical forms (Hillier, 2012). Hence, in order to provide the relation between the social theory and the built environment with "testable design-level propositions", it has been mentioned that the environment-society relation within the "spatiality" paradigm (Hillier, 2008) should replace the society-environment one. In fact, regarding the formation of an organic wholeness (such as the vernacular settlements), public places, streets, social and religious practices are some of the crucial connective elements of the historic cities (Hosagrahar, 2010).

\section{Space Syntax and Spatial Configuration}

Space syntax is an analytical framework (Hillier, 1996; Hillier \& Hanson, 1984) that contributes to the configuration and structural aspects of space (Karimi, 2012). The space syntax approach has been developed in the late 70 s and early $80 \mathrm{~s}$ (Hillier, 1985, 1996, 1999; Hillier \& Hanson, 1984; Steadman, 1983). In fact, space syntax is a theory that attempts to study the relationship between spatial and social attributes (Hillier, Burdett, Peponis, \& Penn 1987; Jiang, Claramunt, \& Klarqvist, 2000). Thus, the space syntax theory is referring to the sociospatial attributes of space, and critically concerned with the aspects that have been conventionally neglected in the architectural theories and urban planning (Al-Sayed \& Turner, 2012). Hence, the theory proclaims that these aspects have a considerable impact on the social life of citizens as well as the behavior of residents (Fisher, 2009; Griffiths, 2011; Hillier \& Iida, 2005). Therefore, the prerequisite to the theory is that the urban space is a product of social relations and the spatial communication between various urban conglomerations predicts the existing behavioral models of the inhabitants (Hillier \& Hanson, 1984). In this way, the syntactic maps have been used for "reading" the spatial configuration of the urban spaces in relation to the social attributes in the context of the city (Kamalipour, Memarian, Faizi, \& Mousavian, 2013; Onder \& Gidi, 2010).

Through the evolutionary process of the theory, the mathematical techniques have been established in order to generate results in graphic manifestations and correlations (Hillier, Hanson, \& Graham, 1986). By analyzing such diagrams and other visual entities, we can provide a framework to study and understand reasons behind disparity and integration or interaction between behavior of people and urban spatial in different times (Chiaradia, Hillier, Barnes, \& Schwander, 2010). For example, using the access graph, one can calculate a number of variables for the study of social interactions (Hillier \& Hanson, 1984; Hillier \& Vaughan, 2007). In this way, the analytical method can be implemented by investigating space units in adjacent spatial configuration and recognizing the hidden patterns in order to understand social relationships and map out the activities that are encompassed in a society (Dursun, 2007).

The parameters of the space syntax are connectivity, global and local integration, and control value. While connectivity measures the number of direct intersected lines, control value indicates the inverse connectivity sum of the adjacent axial lines (Jiang \& Claramunt, 2002). Meanwhile, integration, as a measure of the "relational asymmetry", is defined in relation to the measure of depth, which refers to the number of the distant lines from a given one in a certain number of steps (Jiang \& Claramunt, 2002). It has been previously argued that a highly integrated spatial configuration enables the accumulation of different land uses, "movement economies", and social interac- 
tions in urban public spaces (Hillier, 1996). On the other hand, the parameter of depth is relatively linked to the socio-spatial practices and power relations in the built environment (Dovey, 1999) in terms of the hierarchical dominance, invisibility, and control. In this way, a deep spatial configuration is likely to have the minimum of visibility. Moreover, it has been well justified that how the syntactic analysis of the spatial configuration is crucial for understanding the character of the urban places (Hanson, 1989). In this way, implementing the parameters of integration, connectivity, and depth while considering the environment-society approach and the space syntax theory, the study tends to explore the process of continuity and change through a comparative syntactic and social analysis of the urban public spaces within the case study of the historic walled city of Naein in the last five decades.

\section{Research Methods}

The study implements combinational research methods using the qualitative and quantitative approaches. The methodology includes the descriptive-analytical, comparative simulation, survey, and logical reasoning methods in a case study (Figure 1). In fact, the study tends to bridge the gap through an interdisciplinary research approach. Hence, the research conducts two interrelated studies in terms of the social attributes and spatial configurations of the case study in order to understand the transformation process of the urban public spaces. Furthermore, the study implements direct observation, face-to-face interviews, questionnaire, and desk study.

Using the descriptive statistical analysis of the questionnaire survey alongside with direct observation and face-to-face interviews, the outcome data provides the study with the social and demographic attribute of the case study (Figure 1). Moreover, implementing the space syntax software for the analysis of spatial configuration of the urban public spaces through a simulation, the study conducts a comparative syntactic analysis on the maps of the case study (the historic walled city of Naein).

\section{Data Collection and Field Study}

The fieldwork of the case study research consists of direct observation and individual face-to-face interviews with the local people, who have been living in the case study in order to verify the outcomes of the simulation of the case study. Regarding the explanatory and descriptive purpose of the case study research (Creswell, 2009; Yin, 2009), the study conducts an analytical desk study and field study in terms of the relation between the space syntax theory, urban public spaces and the case study (the historic walled city of Naein). Using the structured questionnaire survey along with direct observation and individual face-to-face interviews, the study conducts the process of data collection in the case study. Moreover, focusing on the relation between social and spatial aspects of the urban studies, the study explores and classifies the social attributes of the urban public spaces of the historic walled city in terms of strength, weakness, opportunity, and threat. Furthermore, the study pursues a descriptive statistical analysis on the demographic attributes of the case study in terms of age, education, employment, marital status, gender, originality, cultural and recreational facilities, maintenance, transportation, construction quality, and overall satisfaction.

In the field study, 112 randomly respondents have participated including the residents of the walled city throughout the

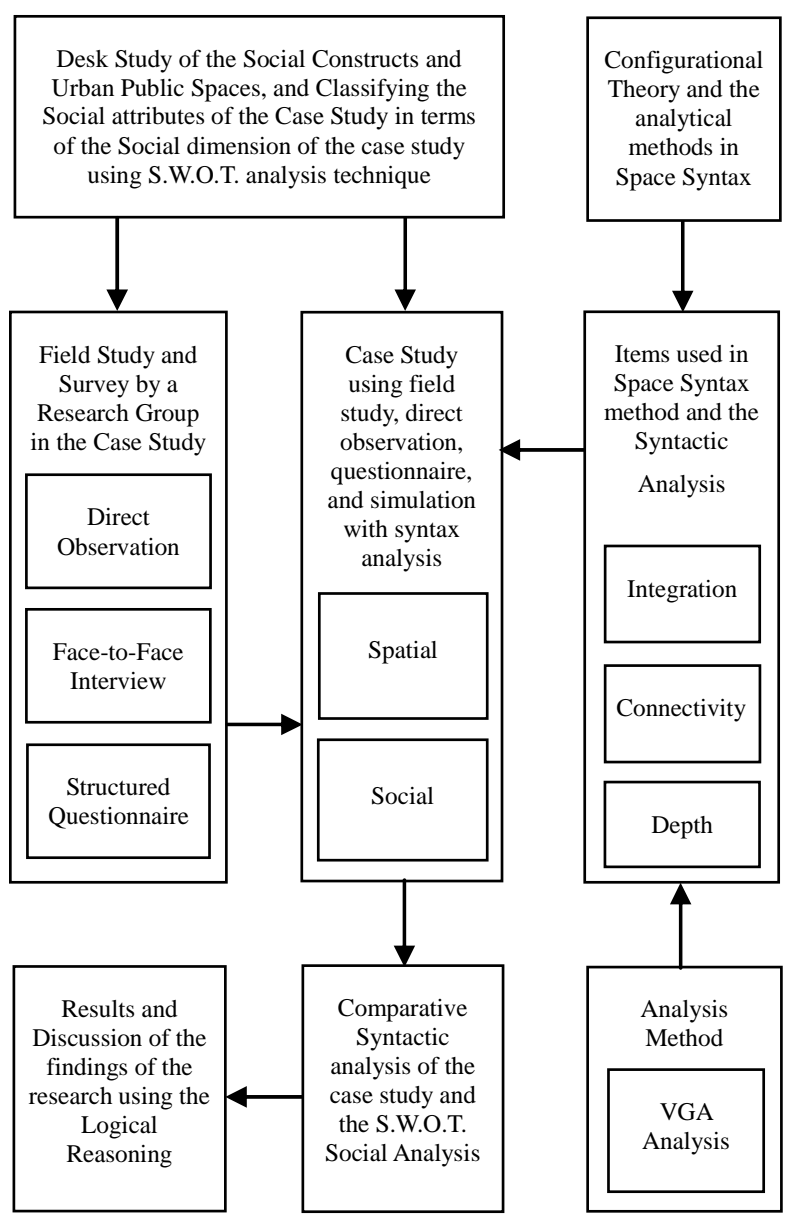

Figure 1.

Research design and steps of the study.

seven residential district. Moreover, the field study includes the questionnaires, direct observations, documentation, and individual face-to-face interviews. A research group, who has been previously provided with the essential information regarding the research process and methods of inquiry in the case study, conducted the fieldwork periodically during about ten days. Meanwhile, a 5-point Likert scale 1) Strongly agree, 2) Agree, 3) No opinion, 4) Disagree, 5) Strongly disagree) is used in order to measure the questionnaire items. Meanwhile, the study involved both men and female respondents, and the participants were selected randomly from different age ranges. However, most of the participants (60\%) were between 25 to 45 years old. Meanwhile, most of them (70\%) have been living within the historic walled city for more than 20 years. Furthermore, the majority of the participants $(60 \%)$ were the owners of their places.

\section{Case Study of the Historic Walled City of Naein}

The traditional city of Naein is located at the central part of Iran near to the deserts of the country, and the historic walled city of Naein is almost distinguishable from the recently developed parts of the city (Figure 2). The historic walled city has seven residential districts, which have been spatially formed through a hierarchical order. The seven residential districts within the historic walled city are Chehel-dokhtaran, Panjahe, 


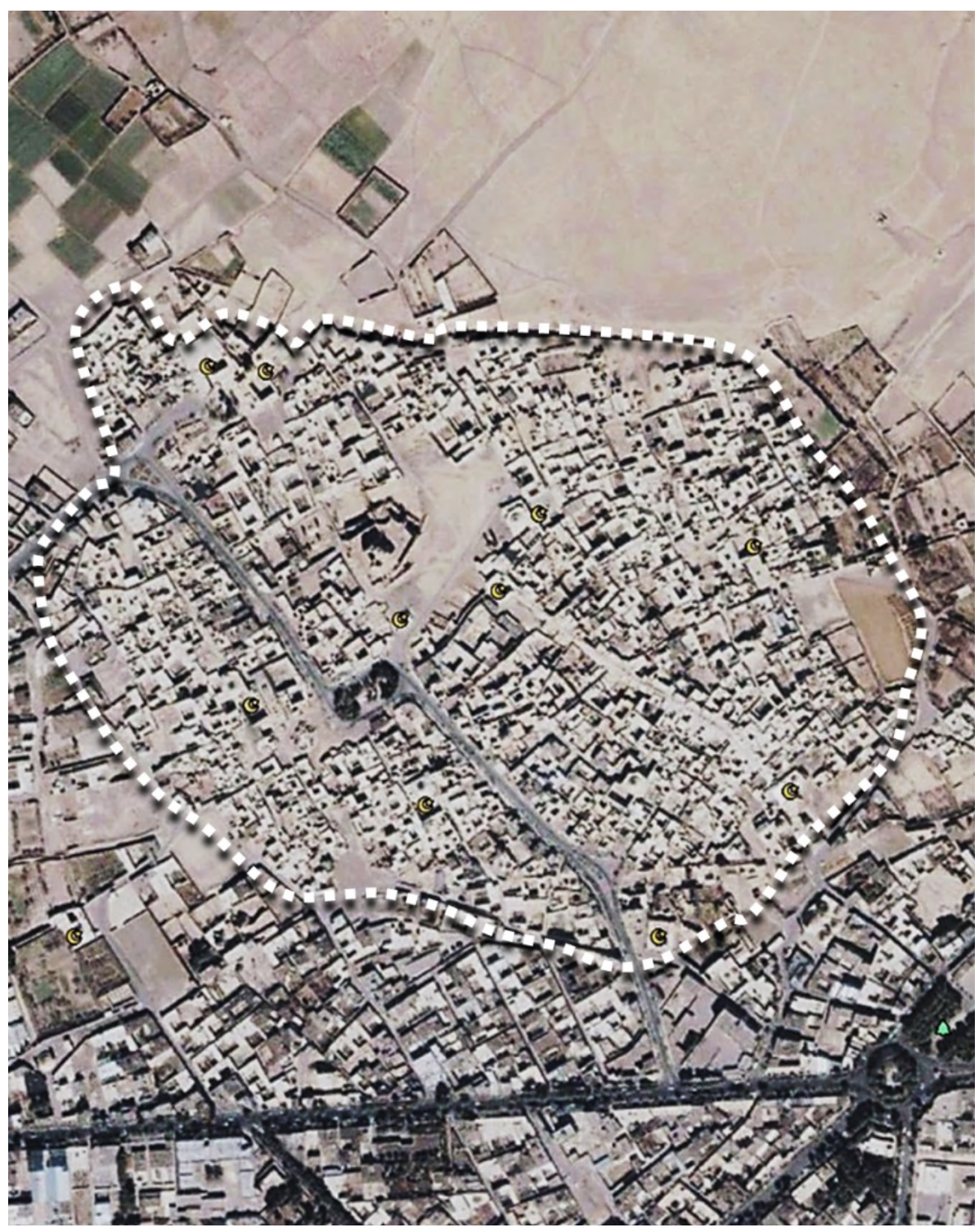

Figure 2.

The location of the historic walled city of Naein adjacent to the central desert of Iran, and near the recently developed parts of the city (Source: Google Earth Maps, Accessed in 10 Sep. 2013).

No-abad, Darb-masjed, Kelvan, Saraye-no, and Kuye-sang (Figure 3). Each district has its own community center, called "Hosseiniyeh" by the vernacular inhabitants due to the religious character of the community centers, especially in the ritual periodic events (Figure 4). Morphologically, the religious character of the public places is relatively distinguishable in the cityscape of the walled city, in which the religious places as the dominant monumental figures of the area (Figure 5). Moreover, the pathways provide the accessibility to the agricultural lands, the Mosques (Figure 6), and the Grand Bazaar (Figure 7) as a part of the public realm (Figure 8). In fact, urban public spaces within the historic walled city of Naein used to have a particular position in the everyday life of the people. In fact, the urban public places within historic walled city of Naein have different types of form and attribute, which can be classified in the four main categories of pathways, commercial places, indoor, and outdoor places (Table 1). However, these places used to ac- commodate different aspects of the people life in terms of daily and periodic activities (Table 1).

\section{Comparative Syntactic Analysis and Simulation}

The study performs a comparative syntactic analysis using the three analysis factors of the space syntax (Connectivity, Integration, and Depth) through a simulation implementing the space syntax software. Since the study tends to explore the urban public spaces, it implements the visibility graph analysis (VGA) method in order to explore the process of continuity and change in relation between social and spatial aspects within the past fifty years. Meanwhile, the visibility point of the comparative syntactic analysis of the depth factor is located at the center of the main urban public space within the walled city. In this way, the comparative simulation of the case study is covering the syntactic analysis of the two maps (belong to 2013 and 
Table 1.

Types of the Urban Public Places in terms of the forms, functional, and social attributes in the historic walled city of Naein (Source: authors).

\begin{tabular}{|c|c|c|c|c|c|}
\hline \multirow{2}{*}{ Types } & \multicolumn{2}{|c|}{ Activity } & \multirow{2}{*}{ Physical Forms } & \multirow{2}{*}{ Functional Attributes } & \multirow{2}{*}{ Social Attributes } \\
\hline & Daily & Periodic & & & \\
\hline Pathways & $*$ & & $\begin{array}{ll}\text { - } & \text { Alleys } \\
\text { - Local pathways } \\
\text { - Local junctions }\end{array}$ & $\begin{array}{l}\text { - Supporting the urban } \\
\text { connectivity } \\
\text { - Accessibility }\end{array}$ & $\begin{array}{l}\text { - Interaction and Social connections } \\
\text { - } \\
\text { - } \\
\text { Placcompanimenthe everyday lifefe }\end{array}$ \\
\hline $\begin{array}{l}\text { Community } \\
\text { Centers }\end{array}$ & $*$ & $*$ & $\begin{array}{ll}\text { - } & \text { Local squares } \\
\text { - } & \text { Surrounded by local } \\
& \text { services and amenities }\end{array}$ & $\begin{array}{l}\text { - The main public place for gath- } \\
\text { ering the local people }\end{array}$ & $\begin{array}{l}\text { - Spending leisure time and daily conversations } \\
\text { - Placing the periodic events in causes } \\
\text { - } \quad \text { Pocaground for children } \\
\text { - Locales as the community centers }\end{array}$ \\
\hline $\begin{array}{l}\text { Major } \\
\text { Commercial } \\
\text { Axis }\end{array}$ & $*$ & & $\begin{array}{l}\text { - } \quad \text { The Grand Bazaar } \\
\text { - Containing the } \\
\text { commercial stores }\end{array}$ & $\begin{array}{l}\text { - Grand Bazaar as the } \\
\text { - } \text { Commercial node } \\
\text { - } \quad \text { Main entrance }\end{array}$ & $\begin{array}{l}\text { - The presence of the commercial owners } \\
\text { - Supporting the connection between the } \\
\text { government and people } \\
\text { - Face-to-face interactions and diversity }\end{array}$ \\
\hline $\begin{array}{l}\text { Religious } \\
\text { Places }\end{array}$ & $*$ & * & $\begin{array}{ll}\text { - } & \text { Mosques } \\
\text { - } & \text { Local Services } \\
\text { - } & \text { Facing an open public } \\
& \text { place }\end{array}$ & 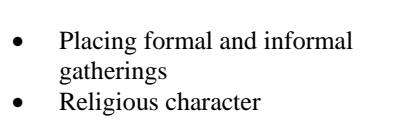 & $\begin{array}{l}\text { - } \quad \text { Placing prayers and Reciting the Quran } \\
\text { - Holding memorial ceremonies } \\
\text { - } \quad \text { Special religious causes } \\
\text { Funeral ceremonies }\end{array}$ \\
\hline
\end{tabular}

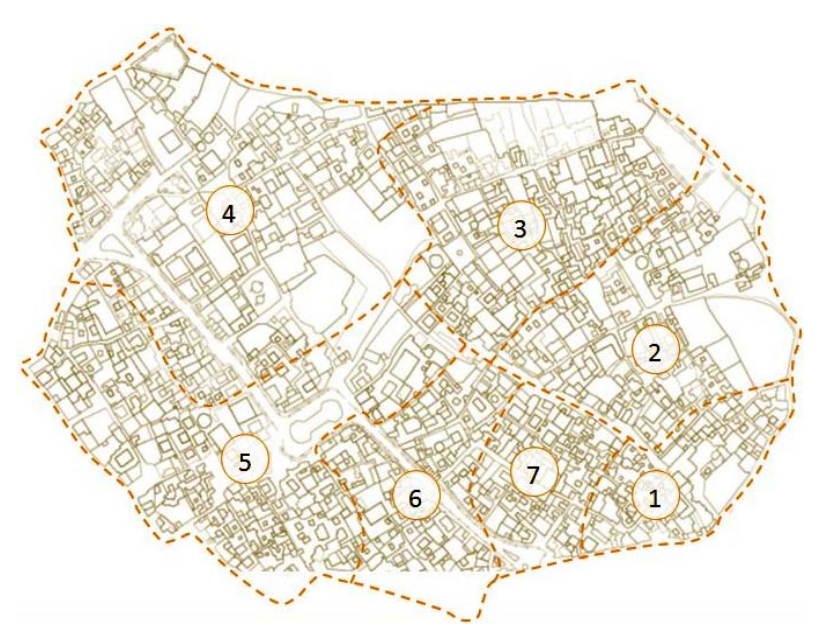

Figure 3.

The seven residential districts in the Naein historic walled city are: Chehel-dokhtaran (1), Panjahe (2), No-abad (3), Darb-masjed (4), Kelvan (5), Saraye-no (6), Kuye-sang (7) (Source: Soltanzadeh, 1995).

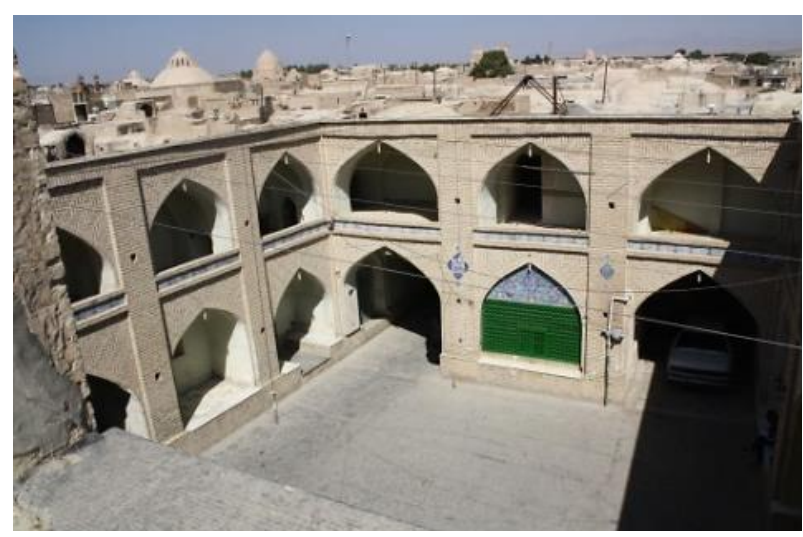

Figure 4.

The community centers, as the open public spaces of the walled city, are the common pattern in the seven districts (Source: authors).
1963) in order to understand the transformation process of the walled city in terms of spatial configuration of the urban public spaces. Therefore, the outcome of the comparative syntactic analysis of the analytical maps includes different space syntax factors (Connectivity, Integration, and Depth), which are recognizable through the syntactic maps in a spectrum from dark red to dark blue.

\section{Results and Discussion}

The results of the study indicate that the public spaces, in their original function, have been responsively used to cover the daily needs of the inhabitants. For example, through the daily activities, the pathways and accessibility network were used in order to provide access to the agricultural lands, Grand Bazaar, and the Mosque. Moreover, these spaces used to accommodate the periodic events. Face-to-face interviews indicate that the vernacular inhabitants have known each other, and they used to engage inclusively with the public realm of the city. In this way, the outcome of the field study suggests that the urban public spaces used to meet the people needs. For example, the Grand Bazar was a place for the religious causes, and the community centers were the places for accommodating daily gatherings. They have also had a religious character in periodic events. Thus, the community centers are surrounded by a diversity of public functions. The indoor public spaces were also in the same positions according to the two aforementioned aspects of life. However, due to the physical and functional deterioration of the city in recent decades, the public spaces are not playing their social role anymore. Similarly, the results of the interviews and questionnaires indicate that most of the participants (72\%) were not satisfied with the maintenance and quality of the public realm. In this way, the results of the field study in terms of face-to-face interviews, questionnaires, and direct observations indicates the analysis of the social dimension in the historic walled city which is provided in terms of strength, weakness, opportunity, and threats (Table 2). However, it seems that the hierarchical formation pattern of the public places has been accompanied with a hierarchical order in the 


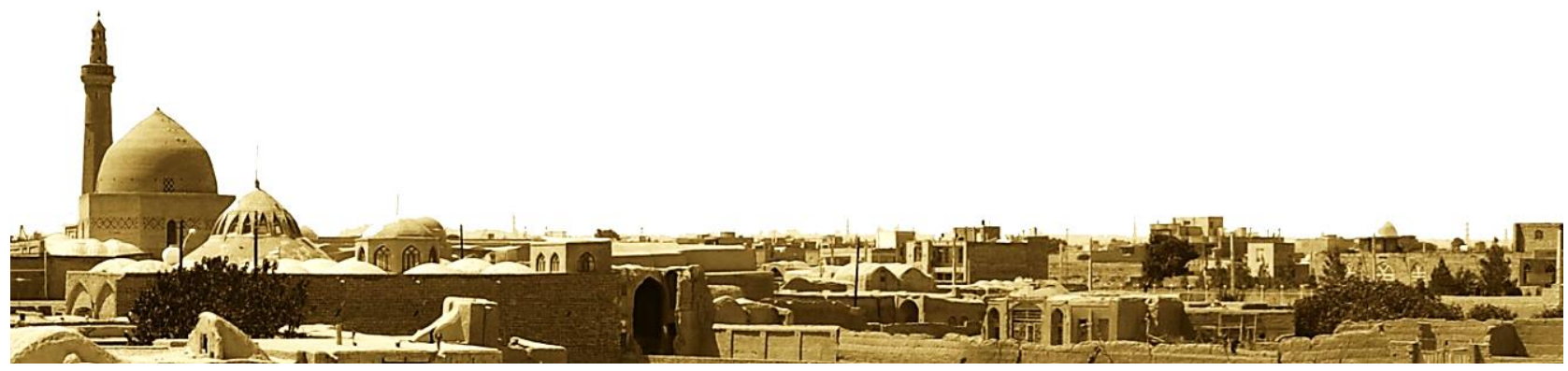

Figure 5.

The religeous places as the dominant monumental figures in the cityscape of the historic walled city of Naein (Source: authors).

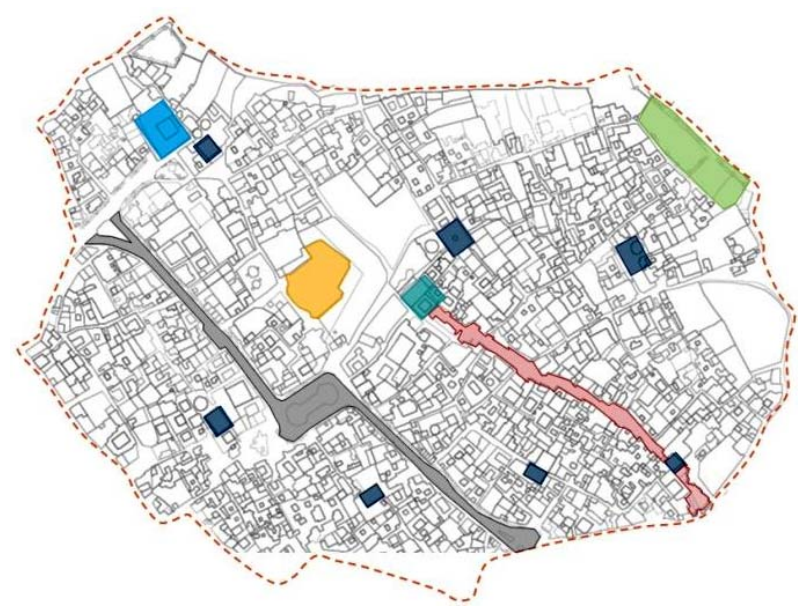

Figure 6.

The Location of Places within the Naein historic walled city: Narin Ghale (Yellow), Community Centers called "Hosseiniyeh" (Dark Blue), Qaraz Street (Grey), Agricultural Lands (Green), Jami Mosque (Light Blue), and the Grand Bazaar (Red) (Source: authors).

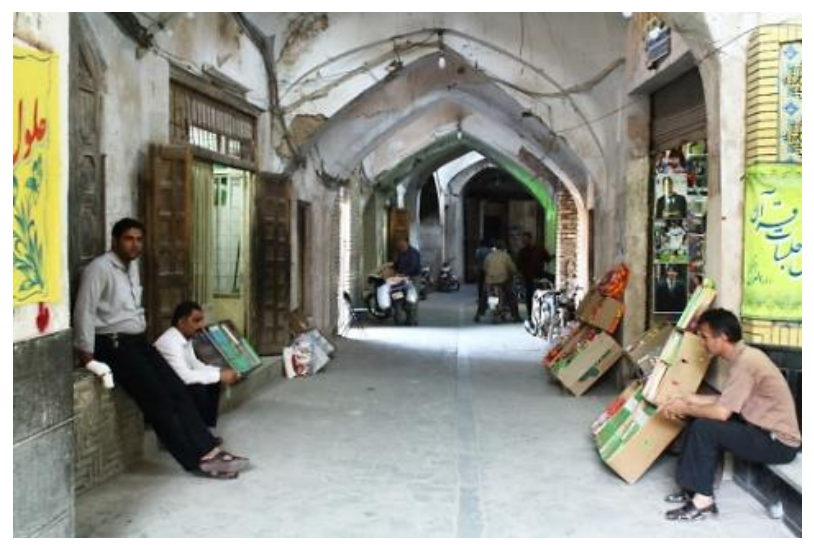

Figure 7.

The Grand Bazaar is the main commercial axis of the city in relation between social and economic constructs (Source: authors).

social interactions. In this way, there is a morphological hierarchical order in the spectrum of the public, semi-public, semiprivate, and private territory.

Firstly, the level of integration has been decreased gradually during the past five decades. Subsequently, the Grand Bazaar has no longer been responsive towards the people needs and the upcoming activities. During the recent five decades, a formal
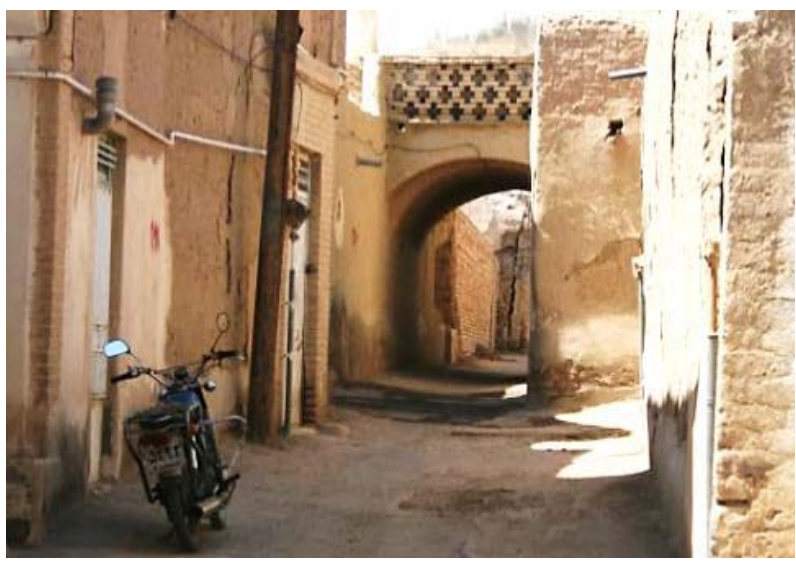

Figure 8.

The pathways and alleys provide the public realm of the walled city with accessibility and urban connectivity (Source: authors).

planning has led to the formation of a new wide street named "Qaraz" as an exclusive commercial axis. The new street has attracted most of the activities, which previously used to take place within the Grand Bazaar and community centres (Figure 9).

Secondly, the level of integration in the Northern parts of the historic context is now relatively higher than the other parts. Conversely, the integration level used to be higher in the Southern parts of the walled city than the other surrounding areas. The results show that the Grand Bazaar and its main entrance gate used to be enormously active in the past. In fact, the Grand Bazaar used to be thoroughly active in the past. Meanwhile, the formation of the Qaraz street and the recent active development of the Jami Mosque, located in the Northern parts of the walled city, have intensified the transformation process of the highly integrated nodes from the Southern parts to the Northern areas of the walled city (Figure 9). Simultaneously, the level of integration in the Western parts of the historic fabric is now relatively higher than the other surrounding areas. Conversely, the integration level used to be higher in the Eastern parts of the walled city than the other parts. The results indicate that the agricultural lands, located in the Eastern parts of the walled city, have become gradually inactive during the past five decades (Figure 9). In this way, the activity nodes have proceeded to the Western parts of the walled city. Since, the Grand Bazaar used to be active in the past decades, the integration level of the adjacent districts, such as the entrance of the Chehel-dokhtaran district, used to be higher than the present status and further districts. 
Table 2.

The analysis of the social dimension in the historic walled city of Naein (Source: authors).

\begin{tabular}{|c|c|c|c|}
\hline Stre & Weakness & Opportunity & Threat \\
\hline $\begin{array}{l}\text { - } \\
\text { - } \quad \text { Mostive focal points (Jami and Narin Ghale) } \\
\text { diversity in community centers } \\
\text { - } \quad \text { Permeability and accessibility } \\
\text { to social nodes and } \\
\text { community centers } \\
\text { - } \text { Active amenities within the } \\
\text { surrounding areas near the } \\
\text { community centers } \\
\text { - Accessibility and permeability } \\
\text { to the Grand Bazaar } \\
\text { - Proximity to the recently } \\
\text { developed residential districts } \\
\text { Social diversity among } \\
\text { vernacular inhabitants } \\
\text { Social surveillance, security } \\
\text { and territoriality within } \\
\text { the walled city } \\
\text { Active social nodes in the } \\
\text { community centers }\end{array}$ & $\begin{array}{l}\text { - The walled city is no longer } \\
\text { providing people needs } \\
\text { The center the walled city has } \\
\text { been moved to the recently } \\
\text { developed districts } \\
\text { - No inclusive places for } \\
\text { children, youth and women } \\
\text { - Lack of the recreational and } \\
\text { cultural facilities } \\
\text { - Generational chasm } \\
\text { - } \quad \text { Tack of vitality } \\
\text { of Bazaar and residential districts } \\
\text { has been tangibly decreased } \\
\text { Low quality of the public realm } \\
\text { (pollution and physical deterioration) } \\
\text { Inhabitants from the low } \\
\text { socio-economic and educational } \\
\text { classes with the lack of social } \\
\text { awareness regarding the value of } \\
\text { the historic buildings }\end{array}$ & 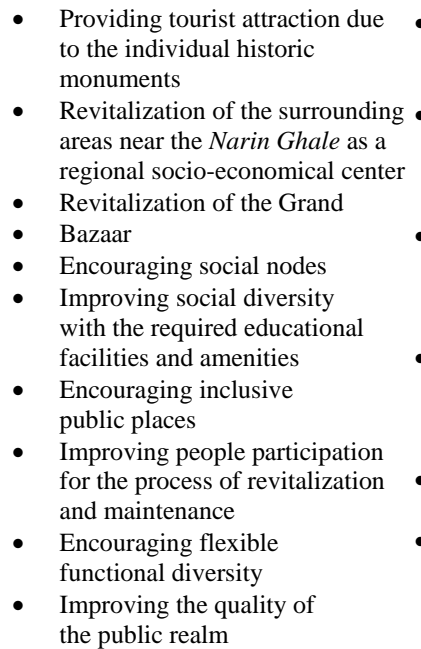 & $\begin{array}{l}\text { - Social Movement to the outside } \\
\text { of the walls due to the lack of } \\
\text { responsive spaces and facilities } \\
\text { The possibility of being abandoned } \\
\text { because of rising insecurity } \\
\text { within the historic urban fabric } \\
\text { of the walled city } \\
\text { The process of the public realm } \\
\text { being excluded for specific } \\
\text { activities and the possibility of } \\
\text { losing diversity } \\
\text { Losing social cohesion because } \\
\text { of the inhabitation of the new } \\
\text { people belonging to the } \\
\text { lower socio-economic classes } \\
\text { The gradual disappearance of } \\
\text { the social activity } \\
\text { Lack of attention to the social } \\
\text { presence of the certain social } \\
\text { groups such as women, children } \\
\text { and youth }\end{array}$ \\
\hline
\end{tabular}

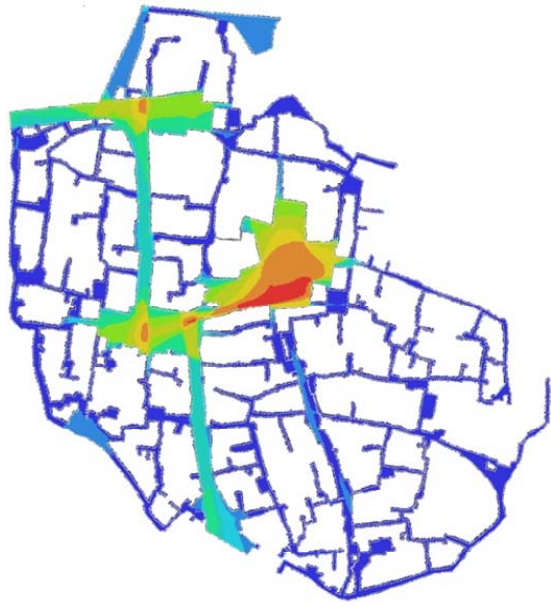

Analysis of the Connectivity factor (2013)

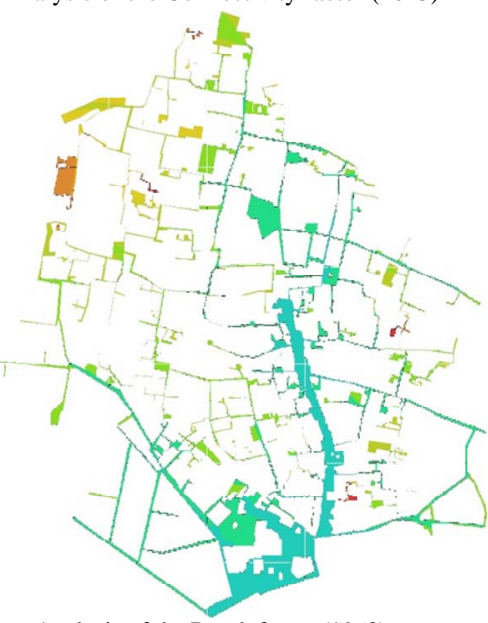

Analysis of the Depth factor (1963)

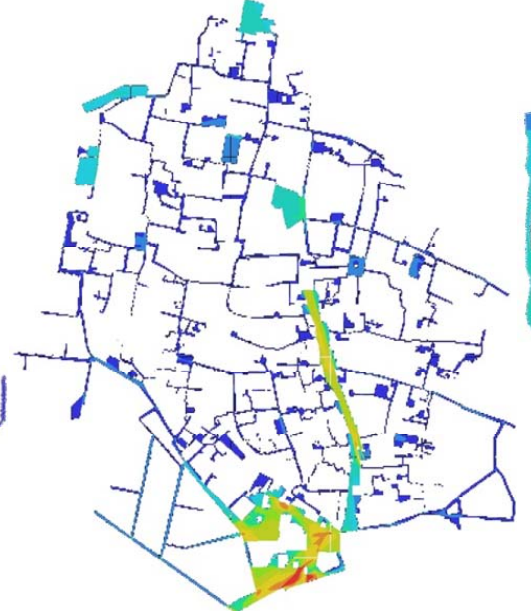

Analysis of the Connectivity factor (1963)

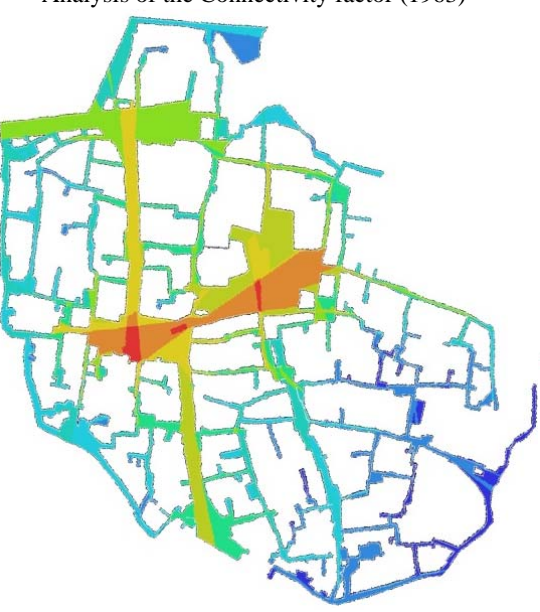

Analysis of the Integration factor (2013)

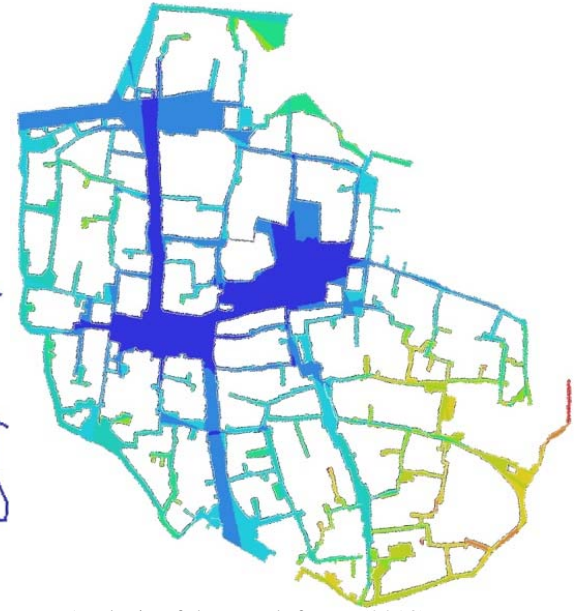

Analysis of the Depth factor (2013)

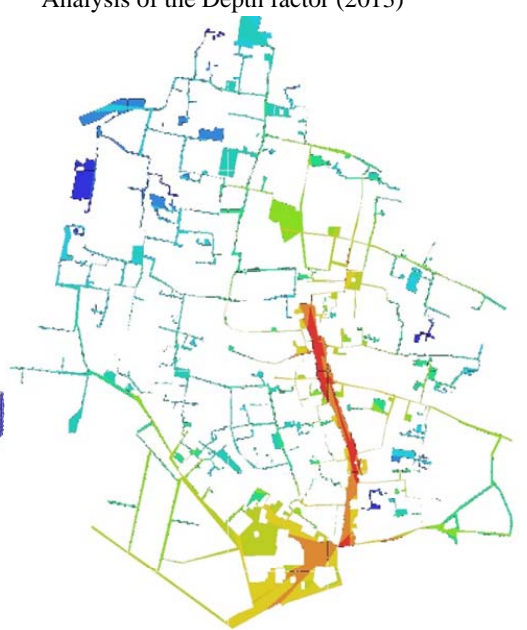

Analysis of the Integration factor (1963)

Figure 9.

The comparative syntactic analysis of the Naein historic walled city in terms of the connectivity, integration, and depth factors indicating the process of the urban transformation within the public spaces from 1963 to 2013 (Source: authors). 
Thirdly, the highest level of integration belongs to the main intersection of the four adjacent districts located at the middle of the historic fabric. However, it seems that the development of the Qaraz street and its square can be the reason of the high level of integration. Conversely, the results indicate that level of integration in the community centres of Panjahe and Cheheldokhtaran is higher than the other centres in the old configuration of the walled city. It should be mentioned that the Panjahe district was located near the highly active agricultural lands in the past. Meanwhile, the field study also shows that a district named "Kelvan" has the highest density among other districts within the walled city both in the past and present time. It should be mentioned that the reasons behind the high density of the Kelvan district are different during the past time in comparison to the present time. However, the accessibility, location, function and level of activity, infrastructure and amenities are now the common attractive features of the Kelvan district.

Fourthly, a historic monument named "Narin-ghale" has been located at the middle parts of the walled city. It is noteworthy to mention that the results demonstrate that the level of integration has not changed during the last five decades. Since the Narin-ghale as a symbolic focal point used to have a historic value, the mental image of the residences has remained unchanged since then. In fact, the direct observation and faceto-face interviews show that the surrounding area of the Naringhale is now might be considered as a "lost space" due to the physical deteriorations, ill-defined shape of the open space, and ruined adjacent areas. In this way, the symbolic monument of the Narin-ghale is no longer the active social node of the walled city. Meanwhile, the community centre of one of the adjacent districts named Panjahe has a high level of integration. However, direct observation does not confirm the outcome due to a tangible low level of activity within the community. It seems that the location of this district, which is near to the Narin-ghale and the former active agricultural lands, might lead to a high level of integration (Figure 9).

Fifthly, the integration level of the Jami Mosque is now higher than it used to be in the last five decades (Figure 9). The results indicate that the surrounding open public spaces have been developed since then. Moreover, the Jami Mosque is now one of the main tourist attraction points of the area. Meanwhile, the Jami Mosque is now located at the end of a highly active streets. However, a community mosque named "Khaje-khezr" has a higher level of integration than the Jami Mosque does. According to the face-to-face interview and direct observation, the Khaje-khezr mosque is more popular related to the everyday life of the people than the Jami Mosque, which has a formal configuration. In other words, the Jami Mosque has been shaped in a formal process that mediates a hidden power in the built environment. Moreover, the Khaje-khezr mosque is now placed at the terminal of a highly active pathway.

Through the process of urban change in contemporary decades, the center of the historic urban fabric of the walled city of Naein has been moved to the recently developed districts. Moreover, the historic urban fabric of the walled city is no longer providing the inhabitants with their basic needs. The results of the study indicate that most of the participants (84\%) were not satisfied with the socio-cultural and recreational facilities within the urban public spaces of the case study. In fact, the historic urban fabric of the walled city is now experiencing the lack of recreational activities and cultural facilities, and there are no socially inclusive spaces available within the his- toric urban fabric; especially, for children, youth and women. Furthermore, the lack of social awareness regarding the value of the historic buildings and context and the low education and socio-economical level of the vernacular inhabitants intensifies the low economic value of the houses and lands within historic urban fabric of the walled city. In this way, most of the inhabitants have moved to the recently developed residential districts. Meanwhile, the lack of educational facilities for children and infants and the lack of vitality and dynamism within the social context intensify the gradual process of generational rupture within the community. Subsequently, the socio-economical function of Bazaar and residential districts, stores and settlements, located in proximity, have been gradually disappeared. However, field study shows the lack of the sense of safety due to the unauthorized speed of the vehicles within the historic urban fabric of the walled city. Moreover, the low quality of the public realm regarding the environmental pollution and physical structure is tangible within the historic urban fabric of the walled city of Naein.

\section{Acknowledgements}

The study has been conducted by a research group organized within the Scientific Association of Architecture in the Shahid Bahonar University of Kerman in Iran. Therefore, the authors would like to acknowledge Siavash Jalaladdini, Mohammad H. Fakharzadeh, Atanaz Dorrani Arab, Elham Rezaeizadeh, Sina S. Shahpasand, Mohammad A. Motedayen, and Hanieh Yazdanfar for giving valuable contributions to the case study of Naein within the organized research group. Furthermore, the authors deeply appreciate the co-operation and kind support of $\mathrm{Mr}$. Afzalaghaei and the Naein Organization of the Cultural Heritage and Tourism.

\section{REFERENCES}

Aghajanian, A. (1995). A new direction in population policy and family planning in the Islamic Republic of Iran. Asia-Pacific Population Journal, 10, 3-20.

Al-Sayed, K., \& Turner, A. (2012). Parametric urban design with space syntax. Fall 2011 International PUARL Conference: Generative Process, Patterns, and the Urban Challenge, Portland.

Alexander, C. (1964). A city is not a tree. Architectural Forum, 122 58-61.

Alexander, C. (1979). The timeless way of building. New York: Oxford University Press.

Alexander, C. (2002). The phenomenon of life: An essay on the art of building and the nature of the universe. Berkeley, Calif.: Center for Environmental Structure.

Barthes, R. (1973). Myth today. In R. Barthes (Ed.), Mythologies. London: Collins; Paladin.

Bentley, I. (1999). Urban transformations: power, people and urban design. London: Routledge.

Bonine, M. E. (1979). The morphogenesis of Iranian cities. Annals of the Association of American Geographers, 69, 208-224. http://dx.doi.org/10.1111/j.1467-8306.1979.tb01252.x

Carmona, M. (2003). Public places, urban spaces: The dimensions of urban design. Boston: Architectural Press.

Carmona, M., Magalhães, C. D., \& Hammond, L. (2008). Public space: The management dimension. New York: Routledge.

Carmona, M., \& Tiesdell, S. (2007). Urban design reader. Boston, MA: Architectural Press.

Carr, S. (1992). Public space. New York, NY: Cambridge University Press.

Carr, S., Francis, M., Rivlin, L. G., \& Stone, A. M. (1992). Needs in public space. In M. Carmona, \& S. Tiesdell (Eds.), Urban Design 
Reader (pp. 230-240). Oxford, UK: Architectural Press.

Chiaradia, A., Hillier, B., Barnes, Y., \& Schwander, C. (2010). Description and discovery in socio-spatial analysis: The case of space syntax. In G. Walford, E. Tucker, \& M. Viswanathan (Eds.), The SAGE Handbook of Measurement. London, UK: SAGE Publications Ltd.

Clark, B. D., \& Costello, V. (1973). The Urban System and Social Patterns in Iranian Cities. Transactions of the Institute of British Geographers, 59, 99-128. http://dx.doi.org/10.2307/621714

Creswell, J. W. (2009). Research design: Qualitative, quantitative, and mixed method approaches (3rd ed.). Thousand Oaks, California: SAGE Publications, Inc.

De Landa, M. (2006). A new philosophy of society: Assemblage theory and social complexity. London; New York: Continuum.

Derrida, J. (1974). Of grammatology (G. C. Spivak, Trans.). Baltimore, MD: Johns Hopkins University Press.

Dovey, K. (1999). Framing places: Mediating power in the built environment. London: Routledge. http://dx.doi.org/10.4324/9780203267639

Dovey, K. (2010). Becoming places: Urbanism/Architecture/Identity /Power. New York: Routledge.

Dursun, P. (2007). Space syntax in archtectural design. 6th International Space Syntax Symposium, Istanbul.

Eade, J., \& Mele, C. (2008). Understanding the City. In J. Eade, \& C. Mele (Eds.), Understanding the City: Contemporary and Future Perspectives (pp. 3-12). Hoboken: John Wiley \& Sons, Ltd.

Fanni, Z. (2006). Cities and urbanization in Iran after the Islamic revolution. Cities, 23, 407-411.

http://dx.doi.org/10.1016/j.cities.2006.08.003

Fisher, K. D. (2009). Placing social interaction: An integrative approach to analyzing past built environments. Journal of Anthropological Archaeology, 28, 439-457.

http://dx.doi.org/10.1016/j.jaa.2009.09.001

Gehl, J. (1987). Life between buildings: using public space. New York: Van Nostrand Reinhold.

Gehl, J., \& Gemzoe, L. (1996). Public spaces, public life. Copenhagen: Danish Architectural Press and the Royal Danish Academy of Fine Arts, School of Architecture.

Griffiths, S. (2011). Temporality in Hillier and Hanson's theory of spatial description: Some implications of historical research for space syntax. Journal of Space Syntax, 2, 73-96.

Hanson, J. (1989). Order and structure in urban design: The plans for the rebuilding of London after the Great Fire of 1666. Ekistics, 56, 22-42.

Hillier, B. (1985). The nature of the artificial: the contingent and the necessary in spatial form in architecture. Geoforum, 16, 163-178. http://dx.doi.org/10.1016/0016-7185(85)90026-0

Hillier, B. (1996). Space is the machine: A configurational theory of architecture. New York: Cambridge University Press.

Hillier, B. (1999). The hidden geometry of deformed grids: Or, why space syntax works, when it looks as though it shouldn't. Environment and Planning B: Planning and Design, 2, 169-191. http://dx.doi.org/10.1068/b260169

Hillier, B. (2008). Space and spatiality: What the built environment needs from social theory. Building Research \& Information, 36, 216230. http://dx.doi.org/10.1080/09613210801928073

Hillier, B. (2012). Studying cities to learn about minds: Some possible implications of space syntax for spatial cognition. Environment and Planning B: Planning and Design, 39, 12-32. http://dx.doi.org/10.1068/b34047t

Hillier, B., \& Hanson, J. (1984). The social logic of space. New York: Cambridge University Press. http://dx.doi.org/10.1017/CBO9780511597237

Hillier, B., Hanson, J., \& Graham, H. (1986). Ideas are in things: An application of the space syntax method to discovering house genotypes environment and planning B: planning and design, 14 , 363385.
Hillier, B., \& Iida, S. (2005). Network and psychological effects in urban movement. Spatial Information Theory: International Conference, COSIT 2005, Ellicottsville.

Hillier, B., Burdett, R., Peponis, J., \& Penn, A. (1987). Creating life: Or, does architecture determine anything? Architecture and Behaviour, 3, 233-250.

Hillier, B., \& Vaughan, L. (2007). The city as one thing. Progress in Planning, 67, 205-230.

Hosagrahar, J. (2010). Cultural heritage. In R. Hutchison (Ed.), Encyclopedia of urban studies (pp. 193-198). California: SAGE Publications. http://dx.doi.org/10.4135/9781412971973.n73

Jacobs, J. (1961). The death and life of great American cities. New York: Random House.

Jiang, B., \& Claramunt, C. (2002). Integration of space syntax into GIS: New perspectives for urban morphology. Transactions in GIS, 6, 295-309. http://dx.doi.org/10.1111/1467-9671.00112

Jiang, B., Claramunt, C., \& Klarqvist, B. (2000). Integration of space syntax into GIS for modelling urban spaces. International Journal of Applied Earth Observation and Geoinformation, 2, 161-171. http://dx.doi.org/10.1016/S0303-2434(00)85010-2

Kamalipour, H., Jalaladini, S., Fakharzadeh, M. H., Motedayen, M. A., \& Dorrani Arab, A. (2012). Urban public spaces and social attributes in the naein historic walled city. ICUCI 2012: International Conference Urban Change in Iran.

Kamalipour, H., Memarian, G., Faizi, M., \& Mousavian, S. M. F. (2013). Evaluating CPTED measures in historical urban public places: A syntactic analysis of a case study. Journal of Basic and Applied Scientific Research, 3, 795-805.

Kamalipour, H., Memarian, G., \& Mousavian, S. M. F. (2012). Exploring the myth of four in the Persian vernacular architecture. IASTE 2012: The Myth or Tradition. Oregon: University of Oregon.

Karimi, K. (2012). A configurational approach to analytical urban design: "Space syntax" methodology. Urban Design International, 17, 297-318. http://dx.doi.org/10.1057/udi.2012.19

Kellett, P., \& Napier, M. (1995). Squatter architecture? A critical examination of vernacular theory and spontaneous settlement with reference to South America and South Africa. Traditional Dwellings and Settlements Review, 6, 7-24.

Lefebvre, H. (1991). The production of space (D. Nicholson-Smith, Trans.). Cambridge, Mass.: Blackwell.

LeGates, R. T., \& Stout, F. (2011). The city reader (5th ed.). New York, NY: Routledge.

Madanipour, A. (1996). Design of urban space: an inquiry into a socio-spatial process. New York: Wiley.

Mitchell, D. (2003). The right to the city: Social justice and the fight for public space. New York: Guilford Press.

Modarres, A. (2006). Urbanization and the revolution: An introduction to the special issue. Cities, 23, 405-406. http://dx.doi.org/10.1016/j.cities.2006.08.005

Norberg-Schulz, C. (1980). Genius loci: Towards a phenomenology of architecture. New York: Rizzoli.

Onder, D. E., \& Gidi, Y. (2010). Reading urban spaces by the spacesyntax method: A proposal for the South Haliç Region. Cities, 27, 260-271. http://dx.doi.org/10.1016/j.cities.2009.12.006

Shaftoe, H. (2008). Convivial urban spaces: Creating effective public places. Sterling, VA: Earthscan.

Soltanzadeh, H. (1995). Naein: Shahr-e hezarehaye tarikh (Naein: The City of millennium history), (In Persian Language). Tehran: Center of Cultural Research Publication.

Steadman, J. P. (1983). Architectural morphology: An introduction to the geometry of building plans. London: Pion.

Tibbalds, F. (1992). Making people-friendly towns: Improving the public environment in towns and cities. Harlow: Longman. http://dx.doi.org/10.4324/9780203469521

Yin, R. K. (2009). Case study research: Design and methods (4th ed.). Vol. 5, Thousand Oaks: SAGE Publications. 